

\title{
Bridging Financial Barrier: A Development of Hybrid Takaful Model towards Quality Mental Health Care Services In Malaysia
}

Khairil Faizal Khairi, Nur Hidayah Laili \& Hisham Sabri

To Link this Article: http://dx.doi.org/10.6007/IJARBSS/v10-i10/8278

DOI:10.6007/IJARBSS/v10-i10/8278

Received: 06 August 2020, Revised: 29 August 2020, Accepted: 18 September 2020

Published Online: 21 October 2020

In-Text Citation: (Khairi et al., 2020)

To Cite this Article: Khairi, K. F., Laili, N. H., \& Sabri, H. (2020). Bridging Financial Barrier: A Development of Hybrid Takaful Model towards Quality Mental Health Care Services In Malaysia. International Journal of Academic Research in Business and Social Sciences, 10(10), 1185-1194.

Copyright: (c) 2020 The Author(s)

Published by Human Resource Management Academic Research Society (www.hrmars.com)

This article is published under the Creative Commons Attribution (CC BY 4.0) license. Anyone may reproduce, distribute, translate and create derivative works of this article (for both commercial and non-commercial purposes), subject to full attribution to the original publication and authors. The full terms of this license may be seen

at: http://creativecommons.org/licences/by/4.0/legalcode

Vol. 10, No. 10, 2020, Pg. 1185 - 1194

http://hrmars.com/index.php/pages/detail/IJARBSS

JOURNAL HOMEPAGE

Full Terms \& Conditions of access and use can be found at http://hrmars.com/index.php/pages/detail/publication-ethics 


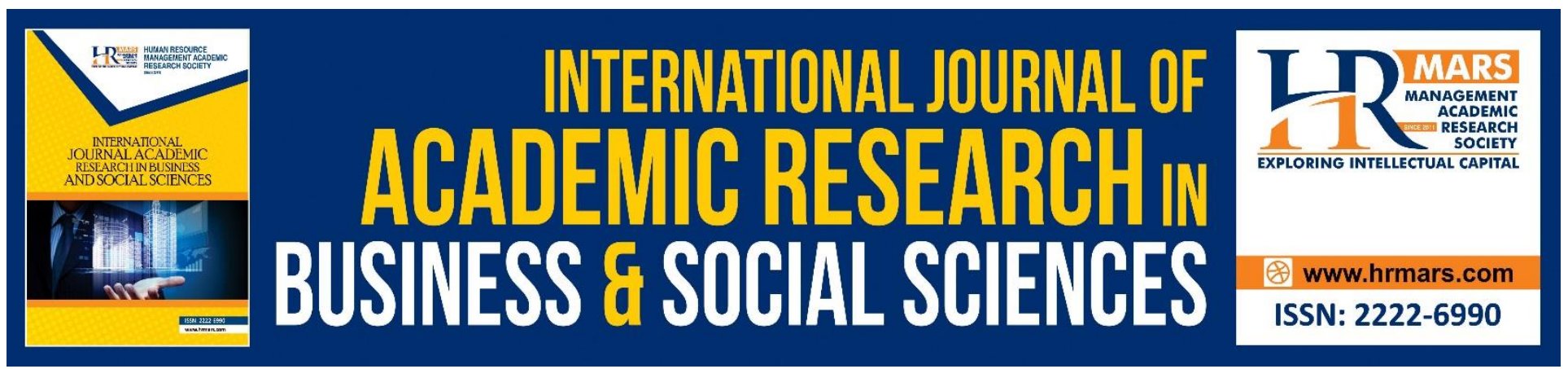

\title{
Bridging Financial Barrier: A Development of Hybrid Takaful Model towards Quality Mental Health Care Services In Malaysia
}

\author{
Khairil Faizal Khairi, Nur Hidayah Laili \& Hisham Sabri \\ Faculty of Economics and Muamalat, Universiti Sains Islam Malaysia (USIM), Malaysia
}

\begin{abstract}
Covering family's members with family takaful is a necessary act in today's environment if the financial risks are to be guarded particularly who are facing with mental health illness. This is due to fact that the cost of mental health services has always been a great barrier to accessing care for people with metal health problems and usually required series of consultations by the expert. Mental health illness becomes one of the major illnesses in Malaysia aside from heart disease that lead for seriously attention among takaful operators to include the mental health treatment in their family takaful premiums due to the worrying number of people suffering from mental health illness. Malaysia is still way behind in offering coverage for mental health illness with only AIA Malaysia and Etiqa Malaysia offers such a policy in the current market and there are huge potential in this product. Consequently, the objective of this paper is to propose a hybrid takaful model for mental health disorders in Malaysia particularly among the lower group of income due to the financial barriers. This paper uses a qualitative approach by analyzing the related document and past literature in achieving the current objective. The outcome from this study concluded that mental health takaful is needed in the Malaysia's market in improving the mental health assessment in the country where the higher level of collaborative effort among the communities as well as governmental and NGOs is mandatory in combating this issue.
\end{abstract}

Keywords: Mental Health Illness, Takaful Operators, Financial Burden, Islamic Finance

\section{Introduction}

Mental health is a state of well-being in which a person is able to realize their full potential, cope with the normal difficulties in life, work successfully and productively as well as being able to make a contribution to the community. Historically, mental health services in Malaysia has long been confined to psychiatry whose history in this country dated back as early as 1827 (Jamaiyah, 2000). However, aspects of prevention of mental disorders and promotion of mental health had lagged behind. The public health burden of mental health disorders now facing at the difficulty stage because it leads the country into major contributor to the burden of disease and disability. Since the mental health disorders is a major of loss of productivity and wellbeing for economic development, the need 
INTERNATIONAL JOURNAL OF ACADEMIC RESEARCH IN BUSINESS AND SOCIAL SCIENCES Vol. 10, No. 10, 2020, E-ISSN: 2222-6990 @ 2020 HRMARS

for a more comprehensive outlook of mental health services especially the role of government, takaful operators and responsible authorities in the country is crucial in addressing this issue.

In is expected that by 2020 the numbers of mental health illness will equal and probably outstrip the cardiovascular disease and cancer more seriously mental health disorders can occur throughout the life span, but the type and nature of the illnesses vary with age. Mental health disorders seem to have increased considerably among adolescents in the past 20-30 years. The rise has been driven by social change, including disruption of family structure, growing youth unemployment, and increasing educational and vocational pressures. These disorders can range from depression, anxiety and autism spectrum disorder to personality and behavioral disorders

A report publish by Organisation for Economic Co-operation and Development (OECD) stated that increasing job insecurity and pressures at work could lead to an aggravation of mental health illness in coming years. Normally most of the people suffering from a mental health illness have a job, but they often have medical leave for long periods of time which lead to the quality of their job. In fact that, three out of five adults with a recent mental health disorder did nor receive care either a general medical provider or a mental specialist (Wang et al., 2005). It is an oversimplification to suggest that all of these people needed proper and profesional treatment for better life of the patients. This statistic is extremely alarming about the mental health disorders problems and takaful operators should play their roles in offering the product that potentially to cover mental health treatment in Malaysia. This is important due to that fact that the costs for getting the professional assistance is higher and the problem is not easy to spot.

The rest of the paper is organized as follows: Section two reviews on the takaful framework and the need of mental health takaful. The discussion on access and cost barrier to mental heatlh care will present in Section three. Meanwhile, section four will develop the hybrid takaful model as an instrument in bridging the financial barrier among the mental health disorders patient. Finally the final section will offer the conclusion of this paper.

\section{Takaful Framework and the Need of Mental Health Takaful}

All human beings are continuously exposed to the possibility of meeting catastrophes and disasters which then lead to a rising to misfortunes and suffering such as death, accident or destruction of business or wealth. Consequently, it required some degree of financial protection against these misfortunes and then the takaful is introduced in the market, which is referred to as compensation or a promise of compensation for specific potential future losses in exchange for a periodic of premium payment. Takaful is an Islamic insurance concept that is grounded in Islamic muamalat offered in the market specifically to counterpart the conventional insurance where the operation and structure of conventional insurance in current practices does not conform to the rules and requirements of Shariah as it embodies a number of misconceptions in its contract and operation. Thus, in order to overcome this situation, Islamic scholars have suggested cooperative or mutual insurance as an alternative to the conventional insurance.

Takaful industry has experienced significant growth and developments, indicating a clear signal of the acceptance of Islamic insurance as am important of enhancing the Shariah protection against vulnerability or rising arising from uncertain event or circumstances. Historically, takaful was first introduced to the public in 1979 in Sudan and has since evolved and developed in several 
INTERNATIONAL JOURNAL OF ACADEMIC RESEARCH IN BUSINESS AND SOCIAL SCIENCES Vol. 10, No. 10, 2020, E-ISSN: 2222-6990 @ 2020 HRMARS

countries as witnessed by the increase in the total amount of takaful contribution (premium) as well as the increase in the number of takaful operators and retakaful players. It have been recorded that the global takaful market reached a value of US\$23.7 billion in 2019 (Global Takaful Report, 2019).

Takaful operation in Malaysia made its inception more than 20 year ago where the takaful industry has emerged as one of the most important Islamic finance components that contribute towards the overall development of the economy of Malaysia. Over the years, this industry keeps their momentum and thus consistently recorded highest growth and proven to be viable and resilient despite the economic and financial shocks and also received competition from the conventional industry. For example, Malaysia recorded largest family takaful market in the world with a growth rate of 16 percent in 2015 (Global Takaful Report, 2017). As at 2019, there are 15 takaful players operating in the Malaysia market as shown in Table 1 below:

Table 1: Number of Takaful Operators in Malaysia

\begin{tabular}{|l|l|l|}
\hline No & Operator & Ownership \\
\hline 1 & AlA Public Takaful Berhad & Foreign \\
\hline 2 & AmMetLife Takaful Berhad & Local \\
\hline 3 & Etiqa Family Takaful Berhad & Local \\
\hline 4 & Etiqa General Takaful Berhad & Local \\
\hline 5 & FWD Takaful Berhad & Local \\
\hline 6 & Great Eastern Takaful Berhad & Foreign \\
\hline 7 & Hong Leong MSIG Takaful Berhad & Local \\
\hline 8 & Prudential BSN Takaful Berhad & Local \\
\hline 9 & Sun Life Malaysia Takaful Berhad & Local \\
\hline 10 & Syarikat Takaful Malaysia Am Berhad & Local \\
\hline 11 & Syarikat Takaful Malaysia Keluarga & Local \\
\hline 12 & Berhad & \\
\hline 13 & Takaful Ikhlas Family Berhad & Local \\
\hline 14 & Zurich General Takaful Malaysia Berhad & Foreign \\
\hline 15 & Zurich Takaful Malaysia Berhad & Foreign \\
\hline
\end{tabular}

The word of Takaful is derived from its Arabic root word 'kafala' which literally means 'to guaranteeing each other or joint guarantee. 'Kafala' define by Alhabshi \& Razak (2009), as the agreement by one party to indemnify another for any liability that has been pre-agreed upon. Besides that AAOIFI (2015, p.678), defined takaful as "a system through which the participants donate part or all of their contributions which used to pay claims for damaged suffered by some of the participant. This definitely enlighten the core concept of takaful which is tabarru' (Yassin \& Ramly, 2011). Tabarru' means donation, gift or contribution which each takaful participant who needs protection must have intention to donate the contributions to the other participants that faced with difficulty (Yasin \& Ramly, 2011). Also, Alhabshi et al, (2012) summarized the fundamental principles of takaful as cooperative insurance that each participating members are willing to contribute some amount of money to the members who face the same risk or danger. 
INTERNATIONAL JOURNAL OF ACADEMIC RESEARCH IN BUSINESS AND SOCIAL SCIENCES Vol. 10, No. 10, 2020, E-ISSN: 2222-6990 @ 2020 HRMARS

The two element under takaful contract which are the element of Tabarru' (donation) and the profit sharing totally eliminates the elements of gharar (uncertainty) and maisir (gambling) in insurance contracts. Conventional insurance have three elements that contradict with takaful (Swartz \& Coetzer, 2010). This is consistent with Ali Khan (2006) where he mentioned that the conventional insurance is prohibited due to the elements of Riba (interest), Gharar (uncertainty) and Maisir (gambling). Malaysia has achieved significant milestones in the development of its takaful industry. With the enactment of the Takaful Act 1984, the first takaful company was established in 1985 . Since then, Malaysia's takaful industry has been gaining momentum and increasingly recognized as a significant contributor to Malaysia's overall Islamic financial system (Bank Negara Malaysia, 2019).

Takaful is one of the protection schemes under Islamic wealth management. The objective of the takaful is to provide protection and assurance against a specific risk that befalls an individual's life or possessions (Aris et al., 2012; Abdullah, 2012; Ahmed, 2013). Besides from that, takaful also counter poverty and deprivation (Fisher, 1999; Patel, 2004; Erlbeck, 2010; Bakhtiari, 2013; Hasim, 2014; Sheila et al., 2015). However majority of takaful operators in Malaysia focus more toward middle and high-income group instead of lower income group (Sheila et al., 2015). This happen due to the majority of lower-income group choose to lapse their policy if there is increase on their takaful plan (Toh, 2017). Despite that, government and private insurers already develop an insurance and takaful scheme for lower income group especially for health insurance (The Star, 2018). This scenario leads to the increasing opportunity of lower income group in subscribing takaful plan. Moreover takaful operator may initiate a new product that suitable for lower income group such as micro takaful (Erlbeck, 2010; Bakhtiari, 2013; Hasim, 2014, Sheila et al., 2015).

Financial barriers are one of the reason on people do not receive good medical treatment for example in the case of mental health disorder patient. Sareen et al., (2007) and Mojtabai (2005) indicated that people often cite concerns about the cost of care or lack of health insurance coverage as reasons for not receiving mental health care. In addition, Sareen et al., (2007) stated that under the National Comorbidity Study, for example, 47 percent of respondents with a mood, anxiety or substance-use disorder who said they thought they needed mental health care cited cost or not having health insurance as a reason they did not receive that care. It is also expected that the numbers of people whom facing mental health disorders lack to seek medical care because the cost may increasing each year.

Majority of Malaysian participate in medical and health takaful as the cost of getting medical treatment is expensive especially in private hospital and critical illness. Currently, there are up to 39 critical illness included in medical and health takaful such as heart disease, cancer, stroke and others. However, majority of the takaful operators does not include the mental health illness in their coverage even though mental health illness recorded as the second highest health problem after heart disease (Institute Public Health, 2015). Malaysia mental health problem among citizen was in dire situation as one in three adult suffering from mental health problems (Lim Su Lin, 2018). Further, Lim Su Lin (2018) mentioned that Malaysian mental health problems dominated by lower income group from year 1995 to 2016 . However there is a continuous rise from high-income earners for mental health illness. There is a significant relationship between income and mental health disorder (Sareen et al., 2011; Bell et al., 2019).

Malaysia is still not aggressively provided takaful and insurance for mental health illness with only AIA Malaysia and Etiqa Malaysia compared to others countries that already make a step forward by including mental health illness in medical and health insurance. As for USA, health insurance plans 
INTERNATIONAL JOURNAL OF ACADEMIC RESEARCH IN BUSINESS AND SOCIAL SCIENCES Vol. 10, No. 10, 2020, E-ISSN: 2222-6990 @ 2020 HRMARS

were required to cover mental health and substance use disorder according to the Affordable Care Act, 2010 (Beronio et al., 2013). Meanwhile AIA Singapore successful launched AIA beyond critical care that provides coverage for mental health conditions. This policy only cover five mental illness which are Major Depressive Disorders (MDD), Schizophrenia, Bipolar Disorder, Obsessive Compulsive Disorder (OCD), and Tourette syndrome (Joanna \& Dawn, 2019). Therefore, Malaysia's takaful operators need to aggressively develop and promoting a takaful plan that cater for mental health conditions as mental health illness is one of the major health problem in Malaysia particularly among lower income family.

\section{Access and Cost Barriers to Mental Health Care}

Mental health causes an enormous burden on affected individuals, their families and society. Positive mental health always linked with a range of the development outcomes. This argument is shown through better health status, higher educational achievement, enhanced productivity and earnings, better parenting and improved quality of life. Meanwhile, in contrasts, poor mental health impedes an individual's capacity to realize their potential, work productivity and make a contribution to their community.

Mental health disorders is common in all countries around the globe, causing immense suffering and staggering economic and social costs especially among the low income countries. The economic burden of mental disorders is huge. The core costs in terms of treatment and service fees by the professionals in the hospital and specialist centers. In addition, the treatment of this health problem technically will take long periods of hospitalization which is more compared to other types of morbidity that usually less chronic. Meanwhile, in terms of indirect costs like that due to loss of productivity at work and job retention and at the worst scenario is leads to unemployment, debt and poverty among the mental health disorders patients and their family. Again, insecurity, low-income levels and malnutrition contribute to mental health disorders and leads to the importance to counter of these issues.

The demand for mental health care among individuals suffering from psychological problems seems to have increased in recent years. There is numerous studies show that people with mental health disorder are less likely to have health insurance than those without mental health problem (McAlpine \& Mechanic, 2000 and Pearson et al., 2009. In addition, Garfield et al., (2011) found that 37 percent of working age adults with severe mental illness were uninsured for at least part of the year compared to about 29 percent of people without severe illness. The statistic is believed to increase higher because of the growing costs of mental health care and prescriptions medications particularly among low-income adults (B40 in the case of Malaysia) and disabled people, has led to a growing cost barrier to such services. Therefore, it is importance for government in providing a new product in market in covering individuals with mental health disorders.

\section{Bridging Financial Barrier Through (W-Takaful Model)}

It is clearly understood from the above section that mental well-being can put at risk by a wide range of factors that span not only the life course but also different level of life, including cognition and behaviour at the individual level, living and working conditions at the social level and opportunities and rights at the broader environmental level. Therefore, it is crucial for the public mental health response to these risks by looking at different level and social groups. The nature of 
INTERNATIONAL JOURNAL OF ACADEMIC RESEARCH IN BUSINESS AND SOCIAL SCIENCES Vol. 10, No. 10, 2020, E-ISSN: 2222-6990 @ 2020 HRMARS

the response not only in promoting or protecting mental health but the most important is about the appropriate treatment and care of people with mental health disorders.

In order for the federal government of Malaysia to ensure the Shared Prosperity Vision 2030 is achieved, the cooperation between government, takaful operators and Islamic Council is mandatory in managing and offering a competitive takaful product in the Malaysia market in uplifting the mental wellness among the community in the country. Consequently, this study proposed a hybrid takaful model for mental health disorders in addition to the current medical scheme through rider takaful. This model is comprises of mudharabah, wakalah and waqf contract where takaful operator will act as fund manager as well as agent to manage the fund from the participant. Furthermore, takaful operator will take a payment upon agent fee from the participants. Meanwhile in the end of investment, surplus will be divided by pre-agreed ratio in profit sharing agreement. The role of waqf in mental takaful products is to balance with the preparation of "rewards for the hereafter". Accordingly, the contribution to fund waqf will be done after the clearance of takaful claims. In fact, the policy have to follow the waqf conditions regarding the distribution of waqf beneficiaries. It may be align with this hybrid model as below:

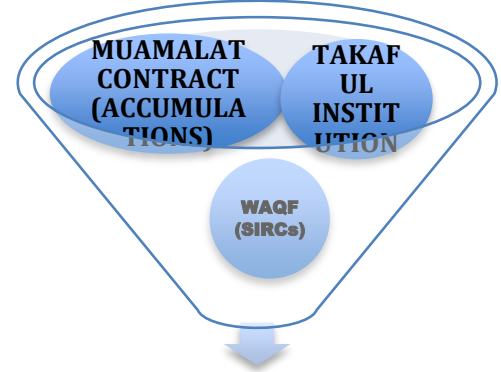

TAKAFUL MENTAL



DISTRIBUTION

CHANNELS

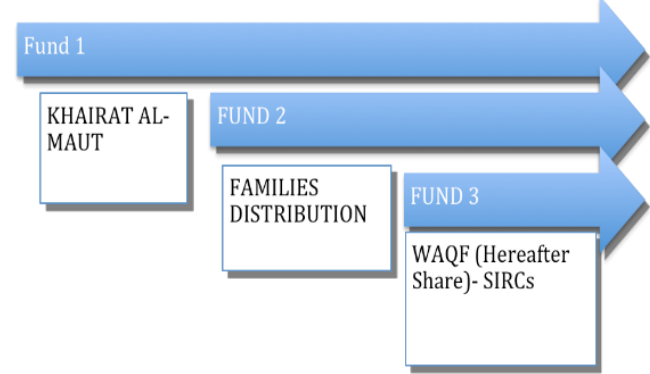

W-Takaful Model (Hisham, Khairil \& Hidayah, 2020)

On the other part of the hybrid model is the role of the government, public, private sectors, medical doctors, depression experts where they can contribute either in term of donations/funds as well as expertise to the mental health disorder patients under the principle of waqf monitored closely by the Islamic Council. This paper is also recommended for government to set-up consortium and allocating special budget under RMK-12, for example "Mental Health Financing Consortium" which the members comprised of Finance Minister, CEO of Takaful operator who interested in offering the takaful scheme, Head of Islamic Council and others responsible authority in monitoring the operation of the system. This special budget is important to boost the confident of private and public to waqf money and expertise to the consortium under this framework. This is important since the professional medical treatment costs for mental health disorder is expected to increase each year and thus, encourage people to seek help from private facilities without worrying about their financial burden. In addition, the method to reduce the risk of mental health is to develop spiritual infrastructure. Therefore, the development of mosques and suraus needs to be created holistically. It also needs to take into account the elements of population density and local economic pressures. The development proposal can be implemented through W-Takaful model. Value of the endowment 
INTERNATIONAL JOURNAL OF ACADEMIC RESEARCH IN BUSINESS AND SOCIAL SCIENCES

Vol. 10 , No. 10, 2020, E-ISSN: 2222-6990 @ 2020 HRMARS

will be channeled for the asset development. Accordingly, the risk of mental health can be reduced through infrastructure-based spiritual facilities.

\section{Conclusion}

Common mental health disorder such as depression can be extraordinarily disabling, yet many people with those illnesses do not receive proper and professional treatment. One of the important reasons where many people with serious disorders do not receive mental health care is due to financial constraint where the cost of care is higher and lack of health takaful coverage. Good mental health manages to support the capability of individuals to display healthy behavior that keeps themselves and others safe in any situations. Moreover, good mental health also facilitates the people perform in keys roles within families, communities and societies, whether taking care of their children and older adults or contributing to their community's economic recovery. The development of infrastructure based on W-Takaful for mental health and spiritual elements can be strengthened for the benefit of human capital in Malaysia. Consequently, related bodies such as the policy maker, takaful operators, NGOs can ensure that mental health agenda is included in coordination and planning both now and for the longer term for benefit of the country.

\section{Acknowledgements}

This paper is a part of a research project entitled: Formulating the Takaful Model under an Islamic Wealth Protection Scheme for Mental Health Disorders towards Societal Wellbeing in Malaysia - project reference code (FRGS/1/2017/SS01/USIM/02/11). The Ministry of Higher Education of Malaysia (MOHE) funds this project.

\section{Corresponding Author}

Khairil Faizal Khairi

Faculty of Economics and Muamalat, USIM, Malaysia, Universiti Sains Islam Malaysia (USIM) Nilai Negeri Sembilan, Malaysia.

Email: khairil@usim.edu.my

\section{References}

Abdullah, S. (2012). Risk Management via Takaful from a Perspective of Maqasid of Shariah. ProcediaSocial and Behavioral Sciences. 65, 535-541.

Alhabshi, S. O., \& Razak, S. H. S. A. (2009). Takaful: Concept, History, Development and Future Challenges of its Industry. Islam and Civilisational Renewal: The Global Financial Crisis. 1(2), 116.

Alhabshi, S. O., Sharif, K., Razak, S. H. S. A., \& Ismail, E. (2012). Takaful Realities \& Challenges. Petaling Jaya, Selangor Darul Ehsan, Malaysia. Pearson Malaysia Sdn Bhd.

Ali, K. (2006). Introduction of Islamic Insurance. Islamic Foundation Bangladesh. Bangladesh.

Aris, N. A., Tapsir, R., \& Talib, M. K. B. A. (2012). Risk and Risk Management of Takaful Industry. Journal of Global Business and Economics. 4(1), 29-39.

Bakhtiari, S. (2013). Microinsurance and Microtakaful: Strategies for Poverty Reduction towards Sustainable Development. OIDA International Journal of Sustainable Development. 6(1), 93100. 
INTERNATIONAL JOURNAL OF ACADEMIC RESEARCH IN BUSINESS AND SOCIAL SCIENCES Vol. 10, No. 10, 2020, E-ISSN: 2222-6990 @ 2020 HRMARS

Bank Negara Malaysia (BNM), (2019). Islamic Banking and Takaful. Retrieved from: http://www.bnm.gov.my/index.php?ch=fs_mfs\&pg=fs_mfs_bank

Bell, C. N., Walton, Q. L., \& Thomas, C. S. (2019). Race and Income Moderate The Association Between Depressive Symptoms and Obesity. Preventive Medicine. 119, 1-6.

Erlbeck, A. (2010). Microtakaful-Insuring the Low-income People in Accordance with the Islamic Law. Master Thesis. Germany: University of Cologne.

Fisher, O. C. (1999). Awakening of a Sleeping Giant-Rediscovery of Takaful Worldwide. Directory of Islamic Insurance (Takaful) 2000, Institute of Islamic Banking \& Insurance.

Garfield, R. L., Zuvekas, S. H., Lave, J. R., \& Donohue, J. M. (2011). The Impact of National Health Care Reform on Adults with Severe Mental Disorders. American Journal of Psychiatry, 168(5), 486494.

Global Takaful Report (2017). Market Trends in Family and General Takaful. Washington D.C.: United States.

Hasim, H. (2014). Microtakaful as an Islamic Financial Instrument, for Poverty Alleviation in Iraq. Middle-East Journal of Scientific Research. 21(12), 2315-2325.

Institute for Public Health. (2015). National Health and Morbidity Survey 2015: Mental Health Problems of Adults. Ministry of Health Malaysia.

Jamaiyah, H. (2000), Community Mental Health in Malaysia: Marriage of Psychiatry and Public Health, Buletin Kesihatan Masyarakat (Keluaran Khas), 155-166.

Joanna, A., and Dawn, T. (2019). First Critical Illness (CI) plan in Singapore to tackle the taboo of mental conditions head-on with the launch of AIA Beyond Critical Care. [online] Aia.com.sg. Available at: https://www.aia.com.sg/en/about-aia/media-centre/pressreleases/2019/launch-of-aia-beyond-critical-care.html [Accessed 27 Feb. 2019].

Lim, S. L. (2018). Bridging Barriers: A study on Improving Access to Mental Healthcare in Malaysia. Retrieved January 29, 2019, from https://penanginstitute.org/programmes/penang-institutein-kuala-lumpur/1032-bridging-barriers-a-study-on-improving-access-to-mental-healthcarein-malaysia/

McAlpine, D. D., \& Mechanic, D. (2000). Utilization of Specialty Mental Health Care among Persons with Severe Mental Illness: The Roles of Demographics, Need, Insurance, and Risk. Health Services Research, 35(1 Pt 2), 277.

Ministry of Health. (2017). Malaysia Mental Health Performance - Technical Report 2016. Retrieved from:

http://www.moh.gov.my/moh/resources/Penerbitan/Laporan/Umum/Mental\%20Healthcare \%20Performance\%20Report\%202016.pdf

Mojtabai, R. (2005). Trends in Contacts with Mental Health Professionals and Cost Barriers to Mental Health Care Among Adults with Significant Psychological Distress in the United States: 19972002. American Journal of Public Health, 95(11), 2009-2014.

Patel, S. (2004). Takaful and Poverty Alleviation. European Economic Review. 48(5), 1-21.

Pearson, W. S., Dhingra, S. S., Strine, T. W., Liang, Y. W., Berry, J. T., \& Mokdad, A. H. (2009). Relationships Between Serious Psychological Distress and the Use of Health Services in the United States: Findings from the Behavioral Risk Factor Surveillance System. International Journal of Public Health, 54(1), 23-29. 
INTERNATIONAL JOURNAL OF ACADEMIC RESEARCH IN BUSINESS AND SOCIAL SCIENCES

Vol. 10, No. 10, 2020, E-ISSN: 2222-6990 @ 2020 HRMARS

Sareen, J., Afifi, T. O., McMillan, K. A., Asmundson, G. J. G. (2011). Relationship between Household Income and Mental Disorders: Findings from a Population-Based Longitudinal Study. Arch Gen Psychiatry. 68(4), 419-427. doi:10.1001/archgenpsychiatry.2011.15

Sareen, J., Jagdeo, A., Cox, B. J., Clara, I., ten Have, M., Belik, S. L., \& Stein, M. B. (2007). Perceived Barriers to Mental Health Service Utilization in the United States, Ontario, and the Netherlands. Psychiatric Services, 58(3), 357-364.

Swartz, N. P., \& Coetzer, P. (2010). Takaful: An Islamic Insurance Instrument. Journal of Development and Agricultural Economics. 2(10), 333-339.

The Star Online. (2018). Government to Pilot B40 Health Insurance. https://www.thestar.com.my/news/nation/2018/11/03/govt-to-pilot-b40-health-insuranceplan/

Toh, B. (2017). Cover Story: Insuring the B40. Retrieved February 27, 2019, from http://www.theedgemarkets.com/article/cover-story-insuring-b40

Wang, P. S., Lane, M., Olfson, M., Pincus, H. A., Wells, K. B., \& Kessler, R. C. (2005). Twelve-Month Use of Mental Health Services In The United States: Results from The National Comorbidity Survey Replication. Archives of General Psychiatry, 62(6), 629-640.

Yassin, N., \& Ramly, J. (2011). Takaful: A Study Guide. IBFIM. 